\title{
Size-related differences in feeding habitat use of adult female loggerhead turtles Caretta caretta around Japan determined by stable isotope analyses and satellite telemetry
}

\author{
Hideo Hatase ${ }^{1, *}$, Noriyuki Takai ${ }^{1, * *}$, Yoshimasa Matsuzawa ${ }^{1, * * *}$, Wataru Sakamoto ${ }^{1}$, \\ Kazuyoshi Omuta ${ }^{2}$, Kiyoshi Goto ${ }^{3}$, Nobuaki Arai ${ }^{4}$, Tateki Fujiwara ${ }^{1}$ \\ ${ }^{1}$ Laboratory of Fisheries and Environmental Oceanography, Graduate School of Agriculture, Kyoto University, Sakyo, \\ Kyoto 606-8502, Japan \\ ${ }^{2}$ Yakushima Sea Turtle Research Group, 489-8 Nagata, Kamiyaku, Kagoshima 891-4201, Japan \\ ${ }^{3}$ Minabe Sea Turtle Research Group, 278 Higashiyoshida, Minabe, Wakayama 645-0001, Japan \\ ${ }^{4}$ Laboratory of Biosphere Informatics, Graduate School of Informatics, Kyoto University, Sakyo, Kyoto 606-8501, Japan
}

\begin{abstract}
Stable isotope analyses and satellite telemetry were used to investigate the relationship between the body size and feeding habitat of adult female loggerhead turtles Caretta caretta around Japan. A total of 149 females from 2 nesting sites, $600 \mathrm{~km}$ apart, 1 in Minabe and 1 in Yakushima, was examined by stable isotope analyses of the egg-yolk in 1998 and 1999. Since there were neither significant intra- nor inter-clutch variations in $\delta^{13} \mathrm{C}$ or $\delta^{15} \mathrm{~N}$ egg-yolks from the same female, the isotope signatures of a single egg-yolk from any clutch in a nesting season could be used to represent those of its nesting female. Both isotopic values increased as the body size of the nesting female increased, irrespective of nesting site. Comparisons between isotopic values of loggerhead egg-yolks and prey items revealed size-related differences among both feeding habits (planktonic or benthic) and habitat areas (pelagic or neritic) of female loggerheads. In 1999, 5 females nesting in Minabe were tracked by satellite. After the nesting season, 2 females with low isotopic values migrated to the pelagic Pacific along the Kuroshio Current, whereas 3 with high isotopic values migrated to the neritic East China Sea. The former females were smaller than the latter. These results were consistent with inferences from stable isotope analyses and previous findings, indicating that the body size, habitat area, and feeding habit of female loggerheads around Japan are closely related. In addition, there were no significant differences in $\delta^{13} \mathrm{C}$ or $\delta^{15} \mathrm{~N}$ between recruits and remigrants, implying that female loggerheads do not change their feeding habitats during the reproductive stage. We postulate that female habitat selection as a function of body size is closely related to the recruitment and settlement in immature loggerheads, which return to Japan after developmental migrations in the North Pacific.
\end{abstract}

KEY WORDS: Caretta caretta $\cdot$ Adult female $\cdot$ Body size $\cdot$ Feeding habitat $\cdot$ Stable isotope analyses $\left(\delta^{13} \mathrm{C}, \delta^{15} \mathrm{~N}\right) \cdot$ Satellite telemetry $\cdot$ Western North Pacific

\footnotetext{
${ }^{*}$ E-mail: hatase@kais.kyoto-u.ac.jp

Present addresses:

${ }^{* *}$ Chugoku National Industrial Research Institute, 2-2-2 Hiro-Suehiro, Kure, Hiroshima 737-0197, Japan

${ }^{* * *}$ Sea Turtle Association of Japan, 5-17-18-302 Nagaomotomachi, Hirakata, Osaka 573-0163, Japan
}

\section{INTRODUCTION}

In the North Pacific, the Japanese Archipelago is the largest nesting ground for the loggerhead sea turtle Caretta caretta (Nishimura 1967, Uchida \& Nishiwaki 
1982, Kamezaki 1986). After hatching on Japanese beaches, loggerhead juveniles grow during a developmental migration in the North Pacific Gyre (Bowen et al. 1995). Loggerheads are largely carnivorous during all life history stages (Dodd 1988, Bjorndal 1997). During the hatchling and juvenile stages, they generally feed on planktonic items such as gelatinous animals in pelagic habitats. During subadult and adult stages, when their swimming and diving abilities are well developed, they generally forage on benthic items such as molluscs, crustaceans, and coelenterates in neritic habitats. Similar results were recorded for the central North Pacific and the Japanese coast through gut-content analyses of incidentally captured and stranded dead turtles (Yamaguchi et al. 1993, Bolten \& Balazs 1995, Kato et al. 1998, Polovina et al. 2000).

On the other hand, recent tag/recapture studies and satellite telemetry conducted on the Japanese nesting beaches have revealed that, during post-nesting seasons, adult female loggerheads migrate not only to neritic habitats (the continental shelves of the East and South China Seas, coastal waters of the Philippines, and coastal waters of Japan where depths are $<200 \mathrm{~m}$ ), but also to pelagic habitats (the Pacific Ocean where depths are $\geq 1000 \mathrm{~m}$ ) (Baba et al. 1992, 1993, Bando 1997, Kamezaki et al. 1997, Sakamoto et al. 1997, Japan Fisheries Resource Conservation Association 1999). Turtles that inhabit the pelagic cannot forage on benthic items, because the maximum dive depth of female loggerheads is $233 \mathrm{~m}$ (during internesting periods: Sakamoto et al. 1990). Instead, they probably feed

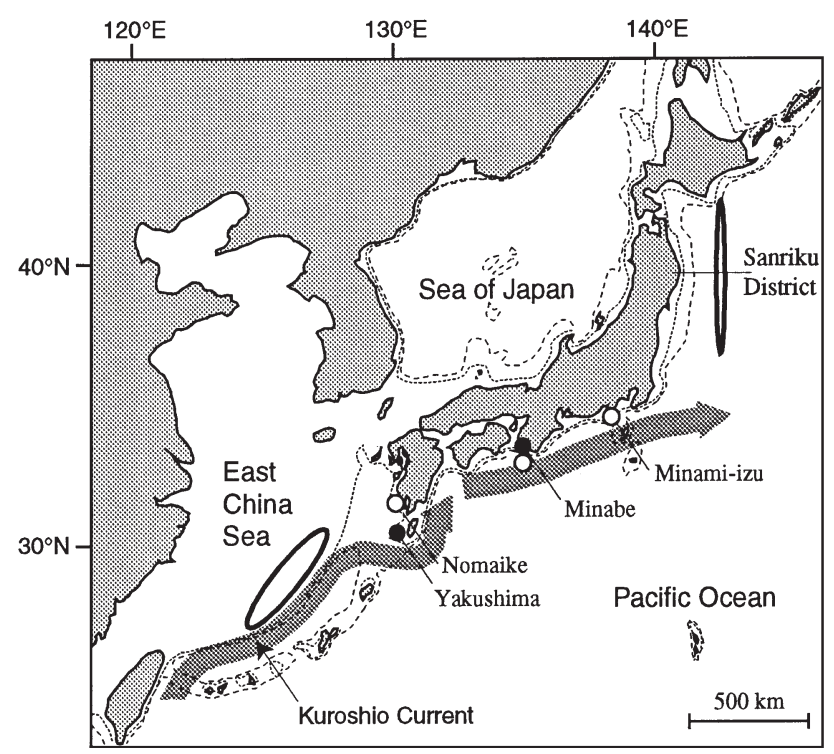

Fig. 1. Sampling locations of the loggerhead turtle Caretta caretta (๑) and prey items $(O$ and areas ringed with thick lines) around the Japanese Archipelago. Broken lines: isobath in meters: ( $\cdots: 200 \mathrm{~m}$; ---: $1000 \mathrm{~m})$; shaded arrows indicate typical stream lines of the warm Kuroshio Current on planktonic items such as jellyfish and salps in the area, as do the hatchlings and juveniles. However, the feeding habits of females inhabiting pelagic areas are not well understood because they are rarely captured in the open ocean. We therefore used stable isotope analysis to determine the feeding habits of female loggerheads in these areas.

Stable isotope analysis has recently been used to study the feeding habits of aquatic animals (see review by Michener \& Schell 1994). The $\delta^{13} \mathrm{C}$ and $\delta^{15} \mathrm{~N}$ of aquatic animals reflect the $\delta^{13} \mathrm{C}$ and $\delta^{15} \mathrm{~N}$ of the diet with ca. $1 \%$ and 3 to $4 \%$ enrichment respectively (DeNiro \& Epstein 1978, Minagawa \& Wada 1984). Consequently, these 2 isotope ratios can be used to identify their diet. In this study, loggerhead eggs were sampled to determine the stable isotope ratios of nesting turtles (Godley et al. 1998). Based on several indices, Rostal et al. (1998) concluded that vitellogenesis in Kemp's ridley Lepidochelys kempi begins 4 to 6 mo prior to the mating period and is completed prior to mating. Although it is not known when vitellogenesis begins and ends in loggerhead turtles, there is a possibility that the timing is similar to that in Kemp's ridley. As female loggerheads rarely feed during the nesting season (Tanaka et al. 1995), the isotope signatures of the yolk of their eggs should reflect the prey consumed in the foraging area before migration to the nesting beach.

We focused on the relationship between the body size and foraging areas of female loggerheads around Japan. Recent satellite telemetry revealed that some small females often migrate to pelagic habitats (Baba et al. 1992, 1993, Japan Fisheries Resource Conservation Association 1999), while large females migrate to neritic habitats. It was therefore hypothesized that body size would be correlated with feeding habits and would be reflected in the differences in the stable isotope signatures. We thus compared the isotope signatures of loggerhead egg-yolks among different size groups, and also with those of prey organisms collected from their foraging areas. Satellite telemetry was also used to verify relationships between body size, foraging areas, and isotope signatures. The number of nesting loggerheads has recently declined at several Japanese nesting sites (e.g. Sato et al. 1997). Determining the habitat use of this endangered species will contribute to its effective conservation and management.

\section{MATERIALS AND METHODS}

Stable isotope analyses. Sampling of loggerhead turtles and prey items: The eggs of loggerhead turtles were collected during nightly patrols from the nesting 
beaches in Minabe $\left(33^{\circ} 46^{\prime} \mathrm{N}, 135^{\circ} 18^{\prime} \mathrm{E}\right)$, Wakayama Prefecture (Senri Beach [1.4 km in length] and the adjacent Iwashiro Beach [1.0 km]), from mid-June to late July in 1998 and 1999, and from the nesting beaches in Yakushima $\left(30^{\circ} 24^{\prime} \mathrm{N}, 130^{\circ} 26^{\prime} \mathrm{E}\right)$, Kagoshima Prefecture (Inaka Beach $[0.8 \mathrm{~km}]$ and the adjacent Mae Beach [0.9 km]), from late May to early June 1999 (Fig. 1). Surveys were conducted every night. Eggs were collected from nests within $24 \mathrm{~h}$ of oviposition. Females were identified by placing tags on either one or both front flippers, or from existing tags. Their straight carapace length (SCL) was measured with calipers. At Senri Beach in Minabe, nesting females have been tagged since 1990, at Iwashiro Beach since 1995 (Sato et al. 1997), and at Inaka and Mae Beaches in Yakushima since 1985 (Omuta 1997). Since female loggerheads return to the same nesting area at ca. 2 yr intervals, a nesting colony consists of recruits and remigrants. Although females move between beaches in each nesting area, there are no other major nesting beaches for these turtles in the areas, and therefore a previously tagged female or a female with tag scars can be regarded as a remigrant, and a newly tagged female without tag scars as a recruit. In Minabe, 12 females were sampled in 1998 and 32 in 1999, while 105 females were sampled in Yakushima in 1999. Only 1 female, nesting in Minabe, was sampled in both years.

Female loggerheads lay several clutches of eggs, $\sim 110$ eggs per clutch, during a nesting season. In this study, one egg was collected per individual female, except for 5 females nesting in Minabe in 1998, for which inter- and intra-clutch variation in stable isotope ratios of the eggs was examined. The $\delta^{13} \mathrm{C}$ and $\delta^{15} \mathrm{~N}$ of the eggs from serial clutches of each of these nesting females were compared. The intra-clutch isotopic variation was also examined for 1 female. We compared the isotopic values of 5 eggs collected per clutch.

Previous findings from tag/recapture studies and satellite telemetry (e.g. Baba et al. 1992, 1993, Kamezaki et al. 1997) indicated that during post-nesting seasons most loggerheads nesting on Japanese beaches inhabit 3 areas: the neritic East China Sea, the coastal waters of Japan, and the pelagic Pacific. Female loggerheads are widely distributed within each area. Prey items were thus collected from these areas. Benthic items (molluscs, crustaceans, coelenterates, and echinoderms) were collected from the neritic East China Sea and the coastal waters of Japan, whereas planktonic items (macroplankton) were collected from the pelagic Pacific. Prey items were collected from late November to early March, taking into account that vitellogenesis in sea turtles is presumed to begin 4 to 6 mo prior to the mating season (Rostal et al. 1998).
Benthic items were collected by trawling from the shelf edge in the East China Sea $\left(27^{\circ} 25^{\prime}\right.$ to $31^{\circ} 35^{\prime} \mathrm{N}$, $124^{\circ} 36^{\prime}$ to $127^{\circ} 16^{\prime} \mathrm{E}$ : Fig. 1) from late January to early February 1999 and 2000. They were also collected by trawling, fishing, and using traps and gill nets in the coastal waters of Japan (Fig. 1) from 1998 to 2000: Minamiizu ( $\left.34^{\circ} 35^{\prime} \mathrm{N}, 138^{\circ} 51^{\prime} \mathrm{E}\right)$, Shizuoka Prefecture, in late December 1999; Minabe, Wakayama Prefecture in mid-November 1998 ; and Nomaike $\left(31^{\circ} 25^{\prime} \mathrm{N}\right.$, $130^{\circ} 08^{\prime}$ E), Kagoshima Prefecture, in early March 2000. Planktonic items were sampled in the Pacific Ocean off the Sanriku District $\left(36^{\circ} 30^{\prime}\right.$ to $42^{\circ} 20^{\prime} \mathrm{N}, 143^{\circ} 30^{\prime}$ to $144^{\circ} 30^{\prime}$ E: Fig. 1) in late November 1999. Planktonic items were obtained by oblique towing with a $1 \mathrm{~m}^{2}$ multiple opening/closing net (0.33 mm mesh size) and environmental sensing system (MOCNESS).

All samples were frozen at $-20^{\circ} \mathrm{C}$ until analytical preparation.

Stable isotope measurements: The egg-yolks of the turtles, the muscle tissue of benthic items, and whole specimens of planktonic items were used for isotopic analyses. Only the salp samples consisted of several individuals. All samples were dried at $60^{\circ} \mathrm{C}$. Lipids were removed with a chloroform-methanol (2:1) solution, and then ground to a fine powder. Only echinoderm samples were later treated with $2 \mathrm{~N} \mathrm{HCl}$ to remove carbonates. Isotope ratios were determined using a Finnigan MAT Delta S mass spectrometer interfaced with a Carlo Erba elemental analyzer. The isotope ratios for 7 egg-yolks from 7 loggerheads nesting in Minabe in 1998 were determined using a Delta S mass spectrometer, following the sealed tube combustion method described by Minagawa et al. (1984). Approximately 0.5 to $1.0 \mathrm{mg}$ of powdered sample was used for $\delta^{13} \mathrm{C}$ and $\delta^{15} \mathrm{~N}$ measurements, except for these 7 samples for which 5.0 to $7.0 \mathrm{mg}$ was used. $\delta^{13} \mathrm{C}$ and $\delta^{15} \mathrm{~N}$ are expressed as the deviation (\%) from the standard defined by the following equation:

$$
\delta^{13} \mathrm{C} \text { or } \delta^{15} \mathrm{~N}=\left(R_{\text {sample }} / R_{\text {standard }}-1\right) \times 1000
$$

where $R$ is ${ }^{13} \mathrm{C} /{ }^{12} \mathrm{C}$ or ${ }^{15} \mathrm{~N} /{ }^{14} \mathrm{~N}$. Belemnite (PDB) and atmospheric nitrogen were used as the carbon and nitrogen isotope standards, respectively. A DL-alanine standard was used for every 8 samples in sequence to assess the analytical precision, which was within $0.2 \%$ for both isotopes $\left(\delta^{13} C_{1} \pm 0.10 \%\right.$; $\delta^{15} \mathrm{~N}, \pm 0.15 \%$; based on the method of Minagawa et al. 1984). Drift in the samples was corrected by comparing the isotopic values of several runs of 10 replicates of a DL-alanine standard measured in this study with those of several 10 replicates previously measured using the method of Minagawa et al. (1984) (e.g. Takai \& Sakamoto 1999, Takai et al. 2000).

Full details of sample locations and isotoperatios are available as appendices at: www.marine.kais.kyoto-u. ac.jp/butsuri/hatase/appendices.html. 
Satellite telemetry. From 21 to 29 July 1999, satellite transmitters (ST-18, Telonics Inc.) were attached with epoxy adhesive and glass-fiber cloth to the carapace of 5 female loggerheads at beaches in Minabe. The SCL and straight carapace width (SCW) were measured with calipers. Body mass was measured with a hanging scale and a net. The front flippers were tagged. Eggs were also collected for stable isotope measurements except in the case of 1 female, whose eggs could not be found.

The females were tracked using the Argos system, which classified their locations into 7 classes of decreasing accuracy: $<150 \mathrm{~m}, 350 \mathrm{~m}, 1 \mathrm{~km}$ for the first 3 $(3,2,1$, respectively), with no accuracy limit for the remaining $4(0, \mathrm{~A}, \mathrm{~B}, \mathrm{Z})$. Locations with Class $3,2,1,0$ or A accuracy were used to reconstruct the migratory routes, except for Turtle 9905 (only 1 location, with Class Z accuracy, was obtained during her tracking). When more than 1 location was obtained within $1 \mathrm{~d}$, the location which could be most accurately classified was adopted. The total distance covered was defined as the sum of the shortest distance between successive locations on the sea surface.

\section{RESULTS}

\section{Intra- and inter-clutch variation in egg-yolk stable isotope ratios}

Isotopic variation in $\delta^{13} \mathrm{C}$ and $\delta^{15} \mathrm{~N}$ of the egg-yolk among the 4 serial clutches ( 5 eggs clutch $^{-1}$ ) of 1 turtle was not significant (Kruskal-Wallis test; $\delta^{13} \mathrm{C}, \mathrm{p}=0.98$ : $\delta^{15} \mathrm{~N}, \mathrm{p}=0.23$ ). Similar results were found for the 2 or 3 serial clutches (1 egg clutch ${ }^{-1}$ ) of 4 other turtles. Standard deviations of the isotopic values of 5 eggs within each clutch of 1 turtle were small, ranging from 0.1 to $0.2 \%$ for $\delta^{13} \mathrm{C}$ and from 0.1 to $0.3 \%$ for $\delta^{15} \mathrm{~N}$. These results indicate that a single egg-yolk from any clutch in a nesting season can reflect the $\delta^{13} \mathrm{C}$ and $\delta^{15} \mathrm{~N}$ of its nesting female. The mean $\delta^{13} \mathrm{C}$ and $\delta^{15} \mathrm{~N}$ values for each of these 5 females were used in the following analyses.

\section{Relationship between body size and stable isotope ratios}

The SCL of sampled females ranged from 760 to $956 \mathrm{~mm}(\mathrm{n}=44)$ at Minabe and from 741 to $968 \mathrm{~mm}(\mathrm{n}=$ 105) at Yakushima. For statistical analyses, the females were divided into 4 size groups: $<800 \mathrm{~mm}$ ( $\mathrm{n}=14$ and 11, Minabe and Yakushima, respectively), 800 to 850 $\mathrm{mm}(\mathrm{n}=14$ and 34$), 850$ to $900 \mathrm{~mm}(\mathrm{n}=12$ and 36$)$, and $\geq 900 \mathrm{~mm}$ ( $\mathrm{n}=4$ and 24) SCL. Females at Yakushima have previously been reported to be significantly larger than those at Minabe (Kamezaki et al. 1995), and our samples revealed the same trend (Fig. 2). The mean ( \pm $\mathrm{SD}) \delta^{13} \mathrm{C}$ values for the 4 size groups were $-18.4 \pm 0.8$, $-18.0 \pm 0.9,-17.1 \pm 0.7$ and $-17.0 \pm 1.2 \%$ respectively, at Minabe, and $-17.8 \pm 1.0,-17.2 \pm 1.0,-16.7 \pm 1.1$ and $-17.1 \pm 1.5 \%$, respectively, at Yakushima (Fig. 2). The mean $( \pm \mathrm{SD}) \delta^{15} \mathrm{~N}$ values were $11.3 \pm 1.1,12.3 \pm 1.5,13.8$ \pm 1.1 , and $14.2 \pm 0.8 \%$, respectively, at Minabe, and $11.8 \pm 1.6,13.1 \pm 1.7,13.9 \pm 1.1$ and $13.5 \pm 0.9 \%$, respectively, at Yakushima (Fig. 2). In these size groups, the $\delta^{13} \mathrm{C}$ and $\delta^{15} \mathrm{~N}$ of the egg-yolk increased significantly with increasing SCL at both nesting sites, except for the SCL of the $\geq 900 \mathrm{~mm}$ group from Yakushima (Kruskal-Wallis test: $\delta^{13} \mathrm{C}, \mathrm{p}<0.005 ; \delta^{15} \mathrm{~N}, \mathrm{p}<0.0005$ at Minabe; $\delta^{13} \mathrm{C}, \mathrm{p}<0.05 ; \delta^{15} \mathrm{~N}, \mathrm{p}<0.005$ at Yakushima; Fig. 2). Irrespective of nesting site, there were highly significant positive correlations between $\delta^{13} \mathrm{C}$ and $\delta^{15} \mathrm{~N}$ in small females $(<800$ and 800 to $850 \mathrm{~mm} \mathrm{SCL})$ (Minabe: Spearman's rank-correlation coefficient $(\rho)=$ 0.64 and 0.93, p $<0.05$ and $<0.001$; Yakushima: $\rho=0.94$ and 0.86, p $<0.005$ and $<0.0001$; Fig. 2); most turtles with a $\delta^{13} \mathrm{C}$ of -19 to $-18 \%$ had a $\delta^{15} \mathrm{~N}$ of 10 to $11 \%$, whereas those with a $\delta^{13} \mathrm{C}$ of -17 to $-16 \%$ had a $\delta^{15} \mathrm{~N}$ of 12 to $15 \%$. In contrast to small females, no highly significant positive correlations between $\delta^{13} \mathrm{C}$ and $\delta^{15} \mathrm{~N}$ were seen in large females (850 to 900 and $\geq 900 \mathrm{~mm}$ SCL) at either nesting site (Minabe: $\rho=0.76$ and 0.80 ,
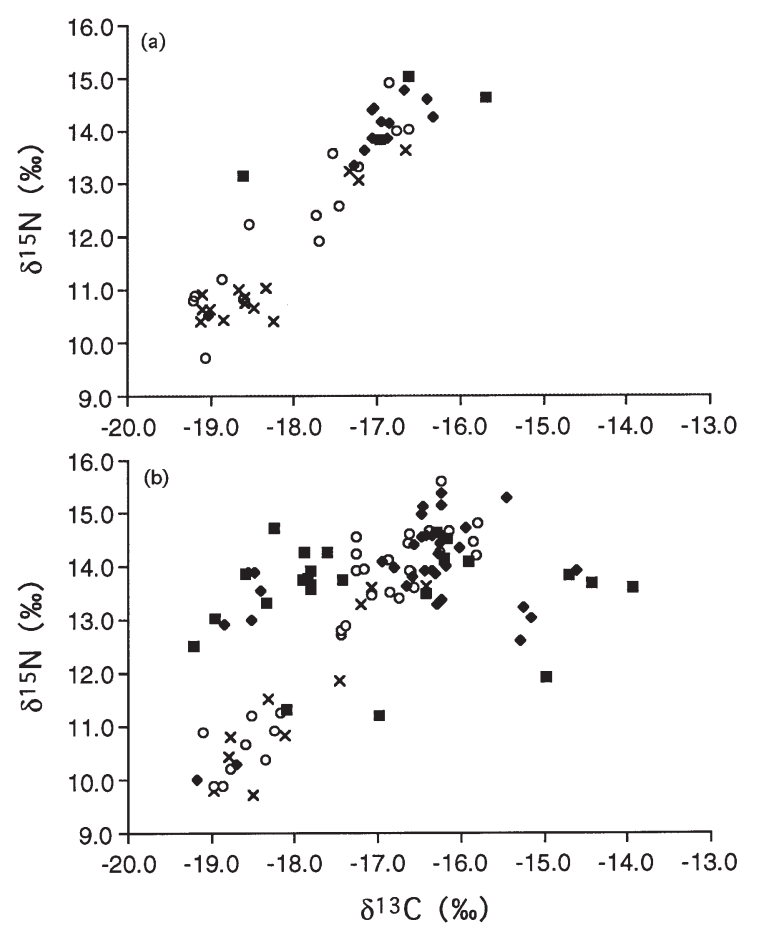

Fig. 2. Caretta caretta. $\delta^{13} \mathrm{C} / \delta^{15} \mathrm{~N}$ maps for eggs collected at (a) Minabe and (b) Yakushima. Sizes (straight carapace length) of individual females which laid the eggs: $(x)<800 \mathrm{~mm}$,

(०) 800 to $850 \mathrm{~mm}_{\text {; }(\bullet)} 850$ to $900 \mathrm{~mm}$, and (•) $\geq 900 \mathrm{~mm}$ 
$\mathrm{p}=0.01$ and not significant (ns); Yakushima: $\rho=$ 0.30 and 0.15 ; ns and ns; Fig. 2); although $\delta^{13} \mathrm{C}$ in large females varyied widely from -19 to $-13 \%$, most had a $\delta^{15} \mathrm{~N}$ of 12 to $15 \%$.

In addition, there were 29 recruits and 15 remigrants in Minabe, 55 and 50 in Yakushima (Table 1). The $\delta^{13} \mathrm{C}$ and $\delta^{15} \mathrm{~N}$ of the egg-yolk displayed no significant differences between recruits and remigrants at either nesting site (Mann-Whitney $U$-test: $\delta^{13} \mathrm{C}, \mathrm{p}=0.95 ; \delta^{15} \mathrm{~N}, \mathrm{p}=$ 0.52 at Minabe; $\delta^{13} \mathrm{C}, \mathrm{p}=0.79 ; \delta^{15} \mathrm{~N}, \mathrm{p}=0.99$ at Yakushima; Table 1), although recruits were significantly smaller than remigrants at Minabe (Student's $t$-test, $\mathrm{p}<0.05$ ) but not at Yakushima.

\section{Comparison between isotope ratios of prey items and loggerhead turtle eggs}

The planktonic organisms collected from the Pacific Ocean off the Sanriku District had mean $\delta^{13} \mathrm{C}$ and $\delta^{15} \mathrm{~N}$ values ranging from $-21.3 \pm 0.0 \% \delta^{13} \mathrm{C}$ (unidentified salp) to $-17.4 \pm 1.3 \% \delta^{13} \mathrm{C}$ (unidentified jellyfish) and from $4.8 \pm 0.0 \% \delta^{15} \mathrm{~N}$ (unidentified salp) to $10.6 \pm 1.1 \% \delta^{15} \mathrm{~N}$ (unidentified jellyfish) (Table 2). The benthic organisms collected from the coastal waters of Japan had mean $\delta^{13} \mathrm{C}$ and $\delta^{15} \mathrm{~N}$ values ranging from $-16.6 \pm 1.5 \% \delta^{13} \mathrm{C}$ (the conch Chicoreus asianus) to $-12.5 \pm 0.5 \% \delta^{13} \mathrm{C}$ (the cephalopod Octopus vulgaris) and from $7.8 \pm 1.6 \% \delta^{15} \mathrm{~N}$ (the conch Chicoreus asianus) to $12.7 \pm 1.0 \% \delta^{15} \mathrm{~N}$ (the cephalopod Todarodes pacificus) (Table 2), whereas the values of the benthic organisms from the East China Sea (except the echinoderm Stellaster equestris) ranged from $-16.3 \pm 0.0 \% \delta^{13} \mathrm{C}$ (the crustacean Parapenaeus sp.) to $-15.1 \pm 0.3 \% \delta^{13} \mathrm{C}$ (the crustacean Kempina mikado) and from $10.3 \pm 0.2 \% \delta^{15} \mathrm{~N}$ (the conch Calliactis japonica) to $12.7 \pm 0.0 \% \delta^{15} \mathrm{~N}$ (the cephalopod Octopus conispadiceus) (Table 2); only the echinoderm $S$. equestris had a remarkably low $\delta^{13} \mathrm{C}(-18.1 \pm 0.1 \%)$ compared to other benthic items (Table 2, Fig. 3). The benthic items from the East China Sea had a generally lower $\delta^{13} \mathrm{C}$ but higher $\delta^{15} \mathrm{~N}$ than those from the coastal waters of Japan (Fig. 3). The isotopic values of planktonic items were generally lower than those of benthic items (Fig. 3).

Small loggerheads had a generally higher ( 2 to $4 \%$ ) $\delta^{15} \mathrm{~N}$ than planktonic prey organisms, resembling the value of benthic organisms (Figs. $2 \& 3$ ), while large loggerheads had a higher $\delta^{15} \mathrm{~N}(\sim 2$ to $5 \%$ ) than either planktonic or benthic organisms (Figs. $2 \& 3$ ). The $\delta^{13} \mathrm{C}$ of planktonic organisms was generally close to that of small loggerheads, whereas that of benthic organisms was close to that of large loggerheads (Figs. 2 \& 3).
Table 1. Caretta caretta. Straight carapace length (SCL; mean \pm SD) f turtles and stable isotope ratios of egg-yolks collected from them. Turtles are grouped by tagging conditions: a newly tagged female without tag scars is regarded as a recruit, while a previously tagged female or a female with tag scars as a remigrant

\begin{tabular}{llcccc} 
Nesting site & Group & $\mathrm{n}$ & $\mathrm{SCL}(\mathrm{mm})$ & $\delta^{13} \mathrm{C}(\%)$ & $\delta^{15} \mathrm{~N}(\%)$ \\
\hline Minabe & Recruit & 29 & $822 \pm 38$ & $-17.7 \pm 0.9$ & $12.5 \pm 1.6$ \\
& Remigrant & 15 & $857 \pm 56$ & $-17.8 \pm 1.2$ & $12.7 \pm 1.8$ \\
Yakushima & Recruit & 55 & $850 \pm 45$ & $-17.0 \pm 1.2$ & $13.3 \pm 1.6$ \\
& Remigrant & 50 & $865 \pm 48$ & $-17.1 \pm 1.2$ & $13.4 \pm 1.3$
\end{tabular}

Relationship between body size, post-nesting habitat areas, and stable isotope ratios

The SCL, SCW, and body mass of 5 female loggerheads (Nos. 9901 to 9905), tracked by satellite, ranged from 760 to $943 \mathrm{~mm}, 606$ to $695 \mathrm{~mm}$, and 63.5 to $110.0 \mathrm{~kg}$, respectively. The loggerheads were tracked for 50 to $172 \mathrm{~d}$ and covered total distances of 193 to $4059 \mathrm{~km}$. Two females (Nos. 9903 and 9905) migrated to the pelagic Pacific along the Kuroshio Current, whereas 3 (Nos. 9901, 9902 and 9904) migrated to the neritic East China Sea (Fig. 4). The former 2 females (812 and $760 \mathrm{~mm} \mathrm{SCL;} 625$ and $606 \mathrm{~mm} \mathrm{SCW;} 64.0$ and $63.5 \mathrm{~kg}$ body mass, respectively) were smaller than the latter 3 (943, 889, and $812 \mathrm{~mm} \mathrm{SCL;} \mathrm{695,} \mathrm{641,} \mathrm{and}$ $663 \mathrm{~mm} \mathrm{SCW}$; 110.0, 100.0 and $85.5 \mathrm{~kg}$ body mass, respectively). In addition, the $\delta^{13} \mathrm{C}$ and $\delta^{15} \mathrm{~N}$ of the eggyolk of the former 2 females $(-19.2$ and $10.9 \%$; -18.7 and $11.0 \%$, respectively) were lower than those of the latter 3 females (-18.6 and $13.2 \%$; no data; -16.8 and $14.0 \%$, respectively).

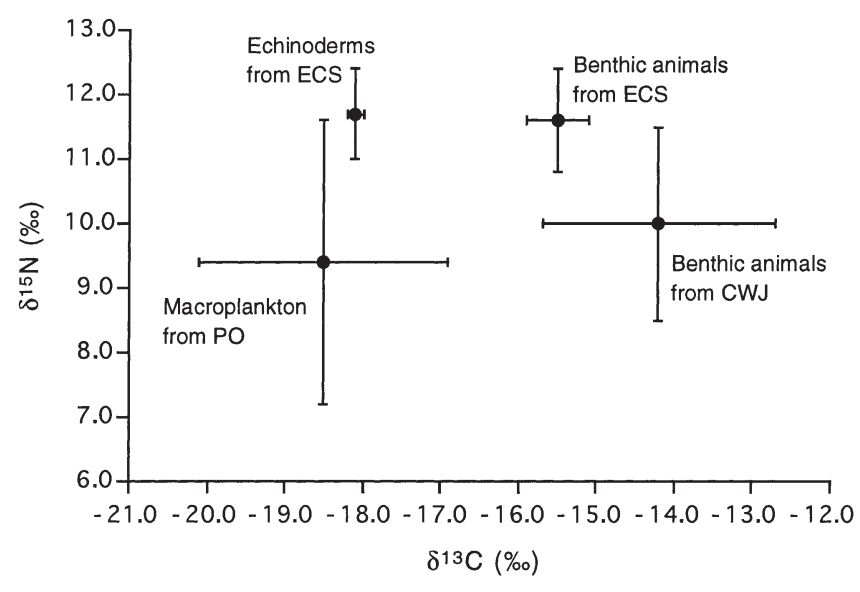

Fig. 3. The $\delta^{13} \mathrm{C} / \delta^{15} \mathrm{~N}$ map of prey items of adult female loggerhead turtles Caretta caretta collected from 3 habitat areas. Values are means \pm SD. PO: Pacific Ocean; CWJ: coastal waters of Japan; ECS: East China Sea 
\& Hattori 1991). Nevertheless, the $\delta^{15} \mathrm{~N}$ of loggerheads was much lower in the Mediterranean than in the western North Pacific, suggesting that large amounts of $\mathrm{N}_{2}$ are fixed in the Mediterranean.

Baba et al. $(1992,1993)$ tracked 5 female loggerheads by satellite from Omaezaki $\left(34^{\circ} 35^{\prime} \mathrm{N}\right.$, $\left.138^{\circ} 14^{\prime} E\right)$, Shizuoka Prefecture, during the post-nesting season, and reported that 3 small females migrated along the Kuroshio Current to the pelagic Pacific, and 2 large females to the coastal waters of Japan. Similar results were obtained by the Japan Fisheries Resource Conservation Association (1999); among 23 female loggerheads tracked from Yakushima, 21 large females migrated to the continental shelf of the East China Sea and coastal waters of

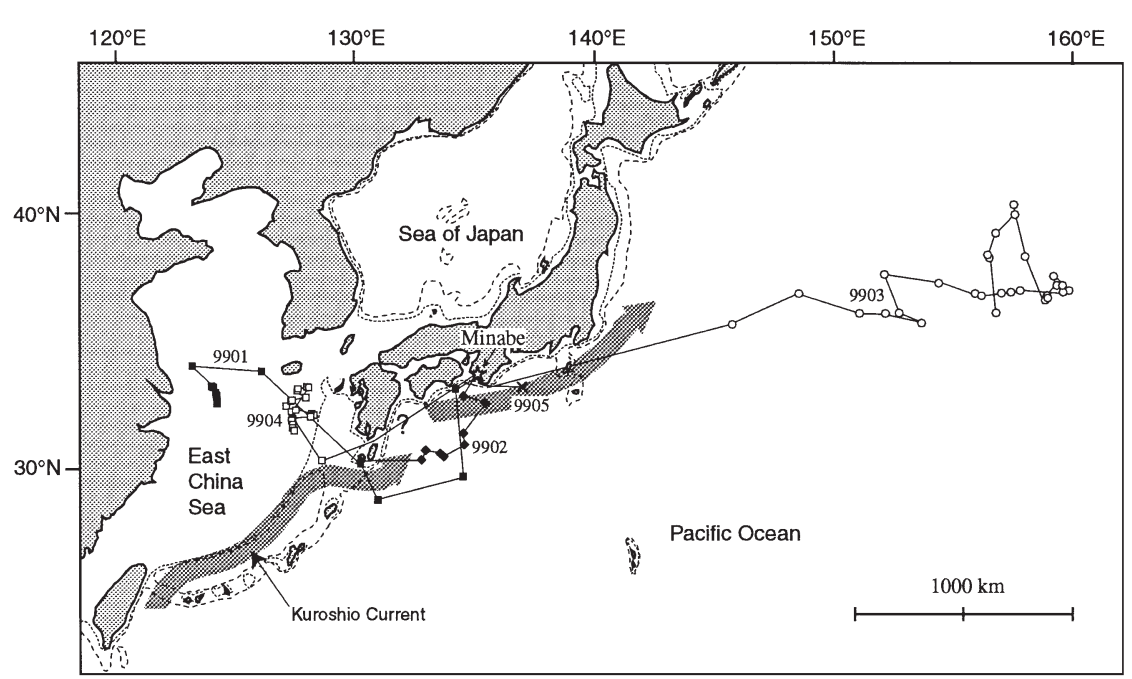

Fig. 4. Caretta caretta. Post-nesting migratory routes of 5 adult females released from Minabe (i) . Broken lines as in Fig. 1; shaded arrows indicate stream lines of the Kuroshio Current during the tracking period (taken from the bulletin of ocean conditions published by the Hydrographic Department of the Japanese Coast Guard). The migratory route of Turtle No. 9904 between Minabe and the first point in the East China Sea is not known, since no transmission was received during the tracking period
Japan, and 2 relatively small

females migrated along the Kuroshio Current toward the pelagic Pacific. These findings suggested that there are size-related differences in the use of feeding habitats by female loggerheads around Japan.

Based on the fact that animal $\delta^{13} \mathrm{C}$ and $\delta^{15} \mathrm{~N}$ are enriched ca. $1 \%$ and 3 to $4 \%$ relative to diet $\delta^{13} \mathrm{C}$ and $\delta^{15} \mathrm{~N}$ (DeNiro \& Epstein 1978, Minagawa \& Wada 1984), in the present study, small females $(<800$ and 800 to $850 \mathrm{~mm} \mathrm{SCL})$ with a $\delta^{13} \mathrm{C}$ of ca. -19 to $-18 \%$ and a $\delta^{15} \mathrm{~N}$ of ca. 10 to $11 \%$ were presumed to have fed primarily on planktonic items in the pelagic (the Pacific Ocean), while small females with a $\delta^{13} \mathrm{C}$ of ca. -17 to $-16 \%$ and a $\delta^{15} \mathrm{~N}$ of ca. 12 to $15 \%$ were presumed to have fed primarily on benthic items in a neritic habitat (possibly the East China Sea). Since most large females ( 850 to 900 and $\geq 900 \mathrm{~mm} \mathrm{SCL}$ ) had a $\delta^{15} \mathrm{~N}$ of ca. 12 to $15 \%$, they also probably fed primarily on benthic items in the neritic habitat. The wide variation in $\delta^{13} \mathrm{C}(-19$ to $-13 \%$ ) in large females arises from their feeding on benthic items with various $\delta^{13} \mathrm{C}$ over a broad range of habitats extending from the coastal waters of Japan to the East China Sea (and possibly including the South China Sea [Kamezaki et al. 1997], although the isotope signatures of benthic items from this sea were not examined in the present study). Satellite tracking results were consistent with these inferences and with previous similar findings. It is therefore concluded that the body size, habitat area, and feeding habit of female loggerheads around Japan are closely related.

What mechanism makes female loggerheads select habitat areas in the western North Pacific as a function of their body size? Female loggerheads grow little after reaching sexual maturity (Hughes 1974, Bjorndal et al. 1983, Limpus 1985); at Minabe, their growth rate is $1.7 \mathrm{~mm} \mathrm{yr}^{-1} \mathrm{SCL}(\mathrm{n}=56, \mathrm{SD}=4.3$; $\mathrm{T}$. Bando unpubl. data). This suggests that their body size would mainly be determined by growth characteristics during the immature period. We therefore propose that their habitat selection as a function of body size is closely related to the recruitment and settlement in immature loggerheads which return to Japan after developmental migrations in the North Pacific. We speculate that immature turtles that recruit to neritic habitats at a small size grow larger by feeding on nutrient-rich prey such as benthos until they reach sexual maturity, whereas immature turtles that stay in the pelagic for a longer period do not grow larger because nutrient-rich prey in this habitat is scarce. In fact, subadult loggerheads (total range 400 to $700 \mathrm{~mm} \mathrm{SCL}$, mean 600 to $700 \mathrm{~mm}$ ) have been captured by set-nets in the coastal waters of Japan (Miyawaki 1994, Hirate 1999), while adults (total range 700 to $950 \mathrm{~mm}$ in curved carapace length, mean 700 to $800 \mathrm{~mm}$ ) have been captured by driftnet and longline fisheries in the pelagic central North Pacific (Wetherall et al. 1993, Polovina et al. 2000). The turtles remain in the respective habitats until sexual maturity, and later return there during the reproductive stage. The lack of significant differences in the 2 isotopic values between recruits and remigrants supports this. The difference in size at which immature turtles return to Japan may result in the sizerelated differences in the use of feeding habitats by 
female loggerheads. Further collection of biological data on loggerheads in the East China Sea and other areas also may help to reveal the mechanism behind this phenomenon.

The number of nesting loggerheads has declined at several Japanese nesting sites since 1990 (e.g. Sato et al. 1997) due to a still unknown cause. Taking into account the present findings, the cause of the decline could roughly be predicted by examining the fluctuations in the mean SCL of female loggerheads present on nesting beaches together with the number nesting. If the cause of the decline exists in the neritic habitat, the mean SCL of female loggerheads nesting on Japanese beaches will become small; if it exists in the pelagic habitat, the mean SCL of females will become large.

Acknowledgements. We thank N. Shiba and many volunteers for helping to collect eggs and attach satellite transmitters to turtles at night on beaches in Minabe and Yakushima, and we thank the Sea Turtle Association of Japan for supplying tags, tagging pliers, and calipers. We are grateful to fishermen of Nomaike in Kagoshima, Minabe in Wakayama, and Minamiizu in Shizuoka for supplying specimens. We also thank S. Onaka and the staff and students of the Laboratory of Forest Ecology, Graduate School of Agriculture, and those of the Center for Ecological Research, Kyoto University, for their technical instructions during our stable isotope analyses. We also acknowledge $\mathrm{T}$. Bando for instructions on attaching the transmitter, and T. Takahashi for helping to deal with telemetric data. N. Baba and N. Tsukada provided some literature. K. Sato provided useful advice on this work. Professor E. Wada critically read this manuscript and provided helpful comments. Finally, we would like to thank 3 anonymous referees for critically reading this manuscript and for many constructive comments. This work was partly supported by grants from the Research Fellowships of the Japan Society for the Promotion of Science (JSPS) for Young Scientists (H.H. and Y.M.) and the Sasakawa Scientific Research Grant from the Japan Science Society to H.H.

\section{LITERATURE CITED}

Baba N, Kiyota M, Suganuma H, Tachikawa H (1992) Research on migratory routes of loggerhead turtles and green turtles by the Argos system. Report on commissioned project for data analysis by scientific observers aboard fishing vessels in 1991. Fisheries Agency of Japan, Tokyo, p 89-99 (in Japanese)

Baba N, Kiyota M, Suganuma H, Tachikawa H (1993) Research on migratory routes of loggerhead turtles and green turtles by the Argos system. Report on commissioned project for data analysis by scientific observers aboard fishing vessells in 1992. Fisheries Agency of Japan, Tokyo, p 86-99 (in Japanese)

Bando T (1997) Fundamental studies on nest site fidelity and migration of the loggerhead turtle, Caretta caretta. Master's thesis, Kyoto University, Kyoto (in Japanese)

Bethoux JP, Copin-Montegut G (1986) Biological fixation of atmospheric nitrogen in the Mediterranean Sea. Limnol Oceanogr 31:1353-1358
Bethoux JP, Morin P, Madec C, Gentili B (1992) Phosphorus and nitrogen behaviour in the Mediterranean Sea. DeepSea Res 39:1641-1654

Bjorndal KA (1997) Foraging ecology and nutrition of sea turtles. In: Lutz PL, Musick JA (eds) The biology of sea turtles. CRC Press, Boca Raton, FL, p 199-231

Bjorndal KA, Meylan AB, Turner BJ (1983) Sea turtle nesting at Melbourne Beach, Florida, I. Size, Growth and reproductive biology. Biol Conserv 26:65-77

Bolten AB, Balazs GH (1995) Biology of the early pelagic stage - the 'lost year'. In: Bjorndal KA (ed) Biology and conservation of sea turtles. Revised edn. Smithsonian Institution Press, Washington, DC, p 579-581

Bowen BW, Abreu-Grobois FA, Balazs GH, Kamezaki N, Limpus CJ, Ferl RJ (1995) Trans-Pacific migrations of the loggerhead turtle (Caretta caretta) demonstrated with mitochondrial DNA markers. Proc Natl Acad Sci USA 92: 3731-3734

DeNiro MJ, Epstein S (1978) Influence of diet on the distribution of carbon isotopes in animals. Geochim Cosmochim Acta 42:495-509

Dodd CK Jr (1988) Synopsis of the biological data on the loggerhead sea turtle Caretta caretta (Linnaeus 1758). Biol Rep 88(14). US Fish and Wildlife Service, US Department of the Interior, Washington, DC

Godley BJ, Smith SM, Clark PF, Taylor JT (1997) Molluscan and crustacean items in the diet of the loggerhead turtle, Caretta caretta (Linnaeus, 1758) [Testudines: Chelonidae] in the eastern Mediterranean. J Mollusc Stud 63: $474-476$

Godley BJ, Thompson DR, Waldron S, Furness RW (1998) The trophic status of marine turtles as determined by stable isotope analysis. Mar Ecol Prog Ser 166:277-284

Hirate K (1999) Loggerhead turtles around the north-western part of Okinawajima. Umigame Newsl Jpn 39:14-15 (in Japanese)

Hughes GR (1974) The sea turtles of South-East Africa. II. The biology of the Tongaland loggerhead turtle Caretta caretta L. with comments on the leatherback turtle Dermochelys coriacea L. and the green turtle Chelonia mydas L. in the study region. Investigational Report No. 36. South African Association for Marine Biological Research, Ocean Research Institute, Durban

Japan Fisheries Resource Conservation Association (1999) Research on migratory routes and diving ecology of sea turtles. General report on commissioned project for conservation research of aquatic animals in 1994-1998, Vol 1. Japan Fisheries Resource Conservation Association, Tokyo, p 1-90 (in Japanese)

Kamezaki N (1986) Notes on the nesting of the sea turtles in the Yaeyama group, Ryukyu Archipelago. Jpn J Herpetol 11:152-155

Kamezaki N, Goto K, Matsuzawa Y, Nakashima Y, Omuta K, Sato K (1995) Carapace length and width of the loggerhead turtle, Caretta caretta nesting in the coast of Japan. Umigame Newsl Jpn 26:12-13 (in Japanese)

Kamezaki N, Miyawaki I, Suganuma H, Omuta K and 7 others (1997) Post-nesting migration of Japanese loggerhead turtle, Caretta caretta. Wildl Conserv Jpn 3:29-39 (in Japanese with English abstract)

Kato H, Oike T, Osuga T, Genda M, Makino S, Oba M, Sugiura S, Hasegawa M (1998) Stomach contents of stranded sea turtles in Enshu-nada from Lake Hamana westward. Umigame Newsl Jpn 35:13-14 (in Japanese)

Limpus CJ (1985) A study of the loggerhead sea turtle, Caretta caretta, in eastern Australia. PhD dissertation, University of Queensland, St. Lucia 
Michener RH, Schell DM (1994) Stable isotope ratios as tracers in marine aquatic food webs. In: Lajtha K, Michener RH (eds) Stable isotopes in ecology and environmental science. Blackwell, Oxford, p 138-157

Minagawa M, Wada E (1984) Stepwise enrichment of ${ }^{15} \mathrm{~N}$ along food chains: further evidence and the relation between $\delta^{15} \mathrm{~N}$ and animal age. Geochim Cosmochim Acta 48:1135-1140

Minagawa M, Wada E (1986) Nitrogen isotope ratios of red tide organisms in the East China Sea: a characterization of biological nitrogen fixation. Mar Chem 19:245-259

Minagawa M, Winter DA, Kaplan IR (1984) Comparison of Kjeldahl and combustion methods for measurement of nitrogen isotope rations in organic matter. Anal Chem 56: 1859-1861

Miyawaki I (1994) Sea turtles captured at the coast of Kushimoto Town, Wakayama Prefecture and their straight carapace lengths. In: Kamezaki N, Yabuta S, Suganuma H (eds) Nesting beaches of sea turtles in Japan. Sea Turtle Association of Japan, Osaka, p 75-80 (in Japanese)

Nishimura S (1967) The loggerhead turtles in Japan and neighboring waters (Testudinata: Cheloniidae). Publ Seto Mar Biol Lab 15:19-35

Omuta K (1997) Turtle tracks in Yakushima Island. Kaiyo Kogaku Kenkyusho Press, Tokyo (in Japanese)

Polovina JJ, Kobayashi DR, Parker DM, Seki MP, Balazs GH (2000) Turtles on the edge: movement of loggerhead turtles (Caretta caretta) along oceanic fronts, spanning longline fishing grounds in the central North Pacific, 1997-1998. Fish Oceanogr 9:71-82

Rostal DC, Owens DW, Grumbles JS, MacKenzie DS, Amoss MS Jr (1998) Seasonal reproductive cycle of the Kemp's ridley sea turtle (Lepidochelys kempi). Gen Comp Endocrinol 109:232-243

Sakamoto W, Uchida I, Naito Y, Kureha K, Tujimura M, Sato K (1990) Deep diving behavior of the loggerhead turtle

Editorial responsibility: Otto Kinne (Editor), Oldendorf/Luhe, Germany near the frontal zone. Nippon Suisan Gakkaishi 56: 1435-1443

Sakamoto W, Bando T, Arai N, Baba N (1997) Migration paths of the adult female and male loggerhead turtles Caretta caretta determined through satellite telemetry. Fish Sci (Tokyo) 63:547-552

Sato $\mathrm{K}$, Bando T, Matsuzawa Y, Tanaka H, Sakamoto W, Minamikawa S, Goto K (1997) Decline of the loggerhead turtle, Caretta caretta, nesting on Senri beach in Minabe, Wakayama, Japan. Chelonian Conserv Biol 2:600-603

Takai N, Sakamoto W (1999) Identification of local populations of Lake Biwa catfish Silurus biwaensis in Japan on the basis of $\delta^{13} \mathrm{C}$ and $\delta^{15} \mathrm{~N}$ analyses. Can J Zool 77:258-266

Takai N, Onaka S, Ikeda Y, Yatsu A, Kidokoro H, Sakamoto W (2000) Geographical variations in carbon and nitrogen stable isotope ratios in squid. J Mar Biol Assoc UK 80: 675-684

Tanaka H, Sato K, Matsuzawa Y, Sakamoto W, Naito Y, Kuroyanagi K (1995) Analysis of possibility of feeding of loggerhead turtles during internesting periods based on stomach temperature measurements. Nippon Suisan Gakkaishi 61:339-345 (in Japanese with English abstract)

Uchida I, Nishiwaki M (1982) Sea turtles in the waters adjacent to Japan. In: Bjorndal KA (ed) Biology and conservation of sea turtles. Smithsonian Institution Press, Washington, DC, p 317-319

Wada E, Hattori A (1991) Nitrogen in the sea: forms, abundances and rate processes. CRC Press, Boca Raton, FL

Wetherall JA, Balazs GH, Tokunaga RA, Yong MYY (1993) Bycatch of marine turtles in North Pacific high-seas driftnet fisheries and impacts on the stocks. Bull Int N Pac Fish Comm 53:519-538

Yamaguchi T, Kato H, Kamezaki N (1993) Stomach contents of stranded loggerhead turtles in the Atsumi Peninsula and the western part of Shizuoka Prefecture. Umigame Newsl Jpn 15:8 (in Japanese)

Submitted: March 19, 2001; Accepted: October 30, 2001 Proofs received from author(s): April 22, 2002 